\title{
HUMAN RING CHROMOSOMES - NEW INSIGHTS FOR THEIR CLINICAL SIGNIFICANCE
}

Guilherme $\mathrm{RS}^{1},{ }^{2}$, Klein $\mathrm{E}^{1}$, Hamid $\mathrm{AB}^{1}$, Bhatt $\mathrm{S}^{1}$, Volleth $\mathrm{M}^{3}$, Polityko $\mathrm{A}^{4}$, Kulpanovich $\mathrm{A}^{5}$, Dufke $\mathrm{A}^{6}$, Albrecht $\mathrm{B}^{7}$, Morlot $\mathrm{S}^{8}$, Brecevic L ${ }^{9}$, Petersen $\mathrm{MB}^{10}$, Manolakos $\mathrm{E}^{10}$, Kosyakova $\mathrm{N}^{1}$, Liehr $\mathrm{T}^{1 *}$

*Corresponding Author: Dr. Thomas Liehr, Institut für Humangenetik, Kollegiengasse 10, Postfach D-07740 Jena, Germany; Tel.: +49-3641-935533; Fax: +49-3641-935582; E-mail: i8lith@mti.uni-jena.de

\footnotetext{
ABSTRACT

Twenty-nine as yet unreported ring chromosomes were characterized in detail by cytogenetic and molecular techniques. For FISH (fluorescence in situ hybridization) previously published high resolution approaches such as multicolor banding (MCB), subcentromere-specific multi-color-FISH (cenM-FISH) and two to three-color-FISH applying locus-specific probes were used. Overall, ring chromosome derived from chromosomes 4 (one case), 10 (one case), 13 (five cases), 14, (three cases), 18 (two cases), 21 (eight cases), 22 (three cases), X (five cases) and Y (one case) were studied. Eight cases were detected prenatally, eight due developmental delay and dysmorphic signs, and nine in connection

${ }^{1}$ Jena University Hospital, Friedrich Schiller University, Institute of Human Genetics, D-07743 Jena, Germany

2 Department of Morphology and Genetics, Universidade Federal de São Paulo, 04023-900 São Paulo, SP, Brazil

${ }^{3}$ Institut für Humangenetik, Otto-von-Guericke-Universität Magdeburg, 39120 Magdeburg, Germany

${ }^{4}$ National Medical Center, 'Mother and Child', 220053 Minsk, Belarus

${ }^{5}$ Belarus State Medical University, 220116 Minsk, Belarus

${ }^{6}$ Institut für Humangenetik, 72076 Tübingen, Germany

${ }^{7}$ Institut f. Humangenetik, Universitätsklinikum Essen, 45122 Essen, Germany

${ }^{8}$ MVZ WagnerStibbe, 30159 Hannover, Germany

${ }^{9}$ School of Medicine Zagreb University, Croatian Institute for Brain Research, 1000 Zagreb, Croatia

${ }^{10}$ Eurogenetica S.A., 11527 Ampelokipoi, Athens, Greece
}

with infertility and/or Turner syndrome. In general, this report together with data from the literature, supports the idea that ring chromosome patients fall into two groups: group one with (severe) clinical signs and symptoms due to the ring chromosome and group two with no obvious clinical problems apart from infertility.

Keywords: Ring chromosomes; Fluorescence in situ hybridization (FISH); Genotype-phenotype correlations.

\section{INTRODUCTION}

It is common sense that ring chromosomes result from two terminal breaks on both chromosome arms followed by fusion of the broken ends, leading to the loss of genetic material. Alternatively, they can be formed by telomere-telomere fusion without deletion [1] or the so-called McClintock mechanism [2]. Also more complex mechanisms of ring chromosome formation have been proposed $[3,4]$. Ring chromosomes are also observed as small supernumerary marker chromosomes (sSMC) [5,6], however, their formation seems to be completely different from that of ring chromosomes in a numerically normal karyotype $[7,8]$.

Phenotypes associated with ring chromosomes can be highly variable, since in addition to the primary deletion associated with ring formation, secondary loss or gain of material may occur due to 
ring chromosome instability. It has also been reported that the phenotype of ring chromosome patients can overlap that of the deletion of both ends of the respective chromosome syndromes without ring formation. Moreover, there have also been numerous reports on ring chromosomes without clinical consequences, apart from possible infertility, if no relevant genetic material was lost due to ring chromosome formation [1]. Here we report ring chromosomes observed in 29 patients with (severe) clinical problems, and/or solely infertility, evaluated by cytogenetic and molecular techniques.

\section{MATERIALS AND METHODS}

Twenty-nine cases with ring chromosomes were studied for different clinical reasons (see Table 1). Eight cases were detected prenatally (amniocytes studied), eight due developmental delay and dysmorphic signs, and nine in connection with infertility and/or Turner syndrome; in four cases the reason for the study was not transmitted to the laboratory at Jena, Germany (peripheral blood studied). Chromosomes were prepared according to standard procedures. The cases were studied using standard banding cytogenetics and by means of FISH (fluorescence in situ hybridization). Previously published high resolution approaches such as multicolor banding (MCB) [9,10], subcentromere-specific multicolorFISH (cenM-FISH) [6] and two to three-color-FISH applying locus-specific and/or commercially available centromere specific probes (Abbott/Vysis, Wiesbaden, Germany and/or Kreatech, Amsterdam, The Netherlands) were used. Locus-specific probes and also commercial probes, such as subtelomeric ones (Abbott/Vysis) or bacterial artificial chromosome

Table 1. Details on the 29 studied ring chromosome cases according to their chromosomal origin, karyotype, age at diagnosis and clinical signs. [DD: developmental delay; DS: dysmorphic signs; IUGR: intrauterine growth retardation; NA: not available; TOP: termination of pregnancy; $y=$ year(s)]

\begin{tabular}{|c|c|c|c|c|}
\hline $\begin{array}{c}\text { Case } \\
\#\end{array}$ & \begin{tabular}{|c|c|}
$\begin{array}{c}\text { Chromosome } \\
\text { of Origin }\end{array}$ \\
\end{tabular} & Karyotype & $\begin{array}{c}\text { Age at } \\
\text { Diagnosis }\end{array}$ & $\begin{array}{c}\text { Clinical } \\
\text { Signs }\end{array}$ \\
\hline $\mathrm{R}-1$ & 4 & 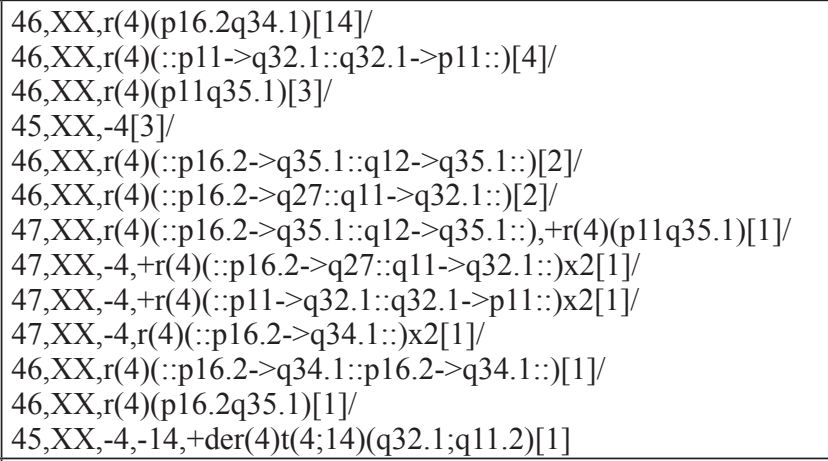 & 5 years & $\begin{array}{l}\text { DD } \\
\text { DS }\end{array}$ \\
\hline R-2 & 10 & $\begin{array}{l}\text { 47,XY,del(10)(q10q25.3),+r(10)(q10q25.3)[23]/ } \\
46, X Y, \operatorname{del}(10)(\mathrm{q} 10 \mathrm{q} 25.3)[6] / \\
47, X Y, \operatorname{del}(10)(\mathrm{q} 10 \mathrm{q} 25.3),+\mathrm{r}(10)(: \because \mathrm{q} 10->\mathrm{q} 25.3:: \mathrm{q} 10->\mathrm{q} 25.3::)[1]\end{array}$ & 5 years & $\begin{array}{l}\text { DD } \\
\text { DS }\end{array}$ \\
\hline R-3 & 13 & $\begin{array}{l}\text { 46,XY,r(13)(p11.2q33.3 34)[9]/ } \\
46, X Y, r(13)(:: p 11.2 q 33.3 \sim 34:: p 11.2 q 33.3 \sim 34::)[1]\end{array}$ & prenatal & $\begin{array}{l}\text { IUGR, DS } \\
\text { TOP }\end{array}$ \\
\hline $\mathrm{R}-4$ & 13 & $\begin{array}{l}\text { 46,XX,r(13)(p11.1q33.3)[13]/ } \\
\text { 46,XX,r(13,13)(::p11.1->q33.3::p11.1->q33.3::)[1]/ } \\
45, X X,-13[1]\end{array}$ & 6 years & $\begin{array}{l}\text { DD, DS } \\
\text { microcephaly } \\
\text { dwarfism }\end{array}$ \\
\hline R-5 & 13 & $\begin{array}{l}\text { 46,XX,r(13)(p11q32.3)[93\%]/ } \\
46, X X, r(13)(:: \mathrm{p} 11->\mathrm{q} 32.3:: \mathrm{p} 11->\mathrm{q} 32.2::)[7 \%]\end{array}$ & adult & $\begin{array}{l}\text { DD } \\
\text { DS }\end{array}$ \\
\hline R-6 & 13 & $\begin{array}{l}45, \mathrm{XX},-13[50] / \\
46, \mathrm{XX}, \mathrm{r}(13)(\mathrm{p} 11.1 \mathrm{q} 33 \sim 34)[50] \\
\end{array}$ & prenatal & $\begin{array}{c}\text { IUGR } \\
\text { TOP }\end{array}$ \\
\hline $\mathrm{R}-7$ & 13 & $46, X Y, r(13)(p 1 ? 2 q 34)$ & NA & NA \\
\hline $\mathrm{R}-8$ & 14 & $\begin{array}{l}\text { 46,XX,r(14)(::p12->q 32.2::q32.2->q23::)[20]/ } \\
\text { 46,XX,r(14)(p12q32.2)[4]/ } \\
\text { 46,XX,del(14)(q21)[1]/ } \\
46, X X[1]\end{array}$ & newborn & $\begin{array}{l}\text { DD } \\
\text { DS }\end{array}$ \\
\hline
\end{tabular}


BALKAN JOURNAL OF MEDICAL GENETICS

Guilherme RS, Klein E, Hamid AB, Bhatt S, Volleth M, Polityko A, Kulpanovich A, Dufke A Albrecht B, Morlot S, Brecevic L, Petersen MB, Manolakos E, Kosyakova N, Liehr T

Table 1. Continued

\begin{tabular}{|c|c|c|c|c|}
\hline $\begin{array}{c}\text { Case } \\
\# \\
\end{array}$ & \begin{tabular}{|c|}
$\begin{array}{c}\text { Chromosome } \\
\text { of Origin }\end{array}$ \\
\end{tabular} & Karyotype & $\begin{array}{c}\text { Age at } \\
\text { Diagnosis }\end{array}$ & $\begin{array}{l}\text { Clinical } \\
\text { Signs }\end{array}$ \\
\hline R-9 & 14 & $\begin{array}{l}46, X Y, r(14)(\mathrm{p} 13 \mathrm{q} 32.2)[82] / \\
45, \mathrm{XY},-14[18]\end{array}$ & 1 year & $\begin{array}{l}\text { DD } \\
\text { DS }\end{array}$ \\
\hline R-10 & 14 & $46, X X, r(14)(\mathrm{p} 1 ? 3 \mathrm{q} 24.3)$ & prenatal & $\begin{array}{l}\text { DS } \\
\text { TOP }\end{array}$ \\
\hline R-11 & 18 & $\begin{array}{l}\text { 46,XX,r(18)(p11.1q12.3 21.1)[7]/ } \\
\operatorname{der}(18)(: \mathrm{p} 11.1->\mathrm{q} 12.3 \sim 21.1:)[12]\end{array}$ & prenatal & NA \\
\hline R-12 & 18 & $\begin{array}{l}46, X X, r(18)(\mathrm{p} 11.21 \mathrm{q} 23)[7] / \\
45, \mathrm{XX},-18[3]\end{array}$ & prenatal & $\begin{array}{l}\text { hydrocephalus } \\
\text { TOP }\end{array}$ \\
\hline R-13 & 21 & $\begin{array}{l}45, \mathrm{XX},-21[50 \%] / \\
46, X X, \mathrm{r}(21)(\mathrm{p} 12 \mathrm{q} 22.3)[30 \%] / \\
46, X X, \operatorname{del}(21)(\mathrm{q} 22.3)[20 \%]\end{array}$ & 11 years & $\begin{array}{l}\text { DD } \\
\text { DS }\end{array}$ \\
\hline R-14 & 21 & $\begin{array}{l}46, \mathrm{XX}, \mathrm{r}(21)(\mathrm{p} 1 ? 3 \mathrm{q} 22.1)[64] / \\
45, \mathrm{XX},-21[26] / \\
46, \mathrm{XX}[10]\end{array}$ & 1 year & $\begin{array}{l}\text { DD } \\
\text { DS }\end{array}$ \\
\hline $\mathrm{R}-15$ & 21 & $\begin{array}{l}\text { 46,XY,r(21)(::p11->q 22::p11q22::)[10]/ } \\
\text { 46,XY,r(21)(::p11->q22::)[7]/ } \\
\text { 45,XY,-21[7]/ } \\
\text { 46,XY,der(21)(:p11->q22::p11->q22:)[2]/ } \\
\text { 46,XY,der(21)(:p11->q22:)[1]/ } \\
\text { 46,XY,r(21)(::p11->q22::p11q2?1::)[1]/ } \\
\text { 46,XY,der(21)(:q22->p11::p11->q22:)[1]/ } \\
47, X Y, r(21)(:: p 11->\mathrm{q} 22::),+\mathrm{r}(21,21)(:: \mathrm{p} 11->\mathrm{q} 22:: \mathrm{p} 11 \mathrm{q} 22::)[1]\end{array}$ & prenatal & $\begin{array}{l}\text { DS } \\
\text { TOP }\end{array}$ \\
\hline R-16 & 21 & $\begin{array}{l}\text { 46,XY,r(21)(p12q22.3)[23]/ } \\
46, X Y, r(21 ; 21)(:: \mathrm{p} 12->\mathrm{q} 22.3:: \mathrm{p} 12->\mathrm{q} 22.3::)[4] / \\
45, \mathrm{XY},-21[2] / \\
46, \mathrm{XY}, \mathrm{r}(21)(\mathrm{p} 12 \mathrm{q} 21)[1]\end{array}$ & prenatal & NA \\
\hline R-17 & 21 & $\begin{array}{l}\text { 46,XY,r(21)(p1?2q22.3)[21]/ } \\
\text { 46,XY,del(21)(:p1?2->q22.3:)[13]/ } \\
46, X Y, r(21)(:: p 1 ? 2->\mathrm{q} 22.3:: \mathrm{q} 22.3->\mathrm{p} 1 ? 2:: \mathrm{p} 1 ? 2->\mathrm{q} 22.3:: \mathrm{q} 22.3->\mathrm{p} 1 ? 2::)[1]\end{array}$ & 32 years & infertility \\
\hline R-18 & 21 & $\begin{array}{l}\text { 46,XY,r(21)(p11.1q22.?2)[9]/ } \\
46, X Y, r(21 ; 21)(:: p 11.1->\mathrm{q} 22 . ? 2:: \mathrm{p} 11.1->\mathrm{q} 22 . ? 2::)[1]\end{array}$ & NA & NA \\
\hline R-19 & 21 & $\begin{array}{l}\text { 46,XN,der(21)(:q11.2->p11.1 11.2::p11.1 11.2->q22.3:)[8]/ } \\
46, \mathrm{XN}, \operatorname{del}(21)(: \mathrm{p} 11.1 \sim 11.2->\mathrm{q} 22.3:)[7] / \\
46, \mathrm{XN}, \mathrm{r}(21)(:: \mathrm{p} 11.1 \sim 11.2->\mathrm{q} 22.3::)[4] / \\
45, \mathrm{XN},-21[1]\end{array}$ & prenatal & NA \\
\hline R-20 & 21 & $\begin{array}{l}\text { 46,XX,r(21)(::p11.2->q } 22.3::)[33] / \\
46, X X, r(21)(:: \mathrm{p} 11.2->\mathrm{q} 22.3:: \mathrm{p} 11.2->\mathrm{q} 22.3::)[5] / \\
47, \mathrm{XX}, \mathrm{r}(21)(: \mathrm{p} 11.2->\mathrm{q} 22.3::),+\operatorname{del}(21)(\mathrm{p} 11.2:)[1] / \\
46, \mathrm{XX}[1]\end{array}$ & 17 years & $\begin{array}{l}\text { premature } \\
\text { ovarian } \\
\text { insufficiency }\end{array}$ \\
\hline $\mathrm{R}-21$ & 22 & $46, \mathrm{XN}, \mathrm{r}(22)(\mathrm{p} 1 ? 2 \mathrm{q} 1 ? 3)$ & $26 \mathrm{y}$ & infertility \\
\hline $\mathrm{R}-22$ & 22 & $46, X Y, r(22)(\mathrm{p} 11 \mathrm{q} 13.3)$ & NA & NA \\
\hline $\mathrm{R}-23$ & 22 & 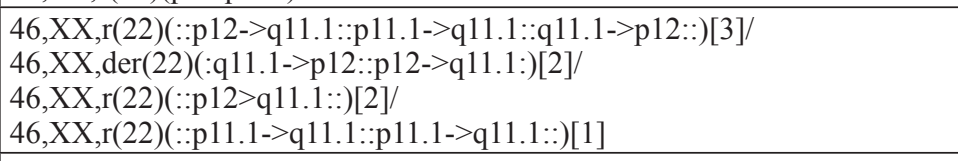 & NA & NA \\
\hline R-24 & $\mathrm{X}$ & $\begin{array}{l}45, X[56] / \\
46, X, r(X)(\mathrm{p} 11.1 \mathrm{q} 24)[44]\end{array}$ & $16 \mathrm{y}$ & Turner syndrome \\
\hline $\mathrm{R}-25$ & $\mathrm{X}$ & $\begin{array}{l}45, \mathrm{X}[19] / \\
46, \mathrm{X}, \mathrm{r}(\mathrm{X})(\mathrm{p} 11.2 \mathrm{q} 13 . ? 1)[11]\end{array}$ & $40 \mathrm{y}$ & infertility \\
\hline R-26 & $\mathrm{X}$ & $\begin{array}{l}45, \mathrm{X}[46] / \\
46, \mathrm{X}, \mathrm{r}(\mathrm{X})(\mathrm{p} 11 . ? 22 \mathrm{q} 13.3)[4] / \\
47, \mathrm{X}, \mathrm{r}(\mathrm{X})(\mathrm{p} 11 . ? 22 \mathrm{q} 13.3) \times 2[1]\end{array}$ & $30 \mathrm{y}$ & Turner syndrome \\
\hline $\mathrm{R}-27$ & $\mathrm{X}$ & $\begin{array}{l}45, \mathrm{X}[17] / \\
46, \mathrm{X}, \mathrm{r}(\mathrm{X})(\mathrm{p} 11.23 \mathrm{q} 28)[7]\end{array}$ & $28 \mathrm{y}$ & infertility \\
\hline $\mathrm{R}-28$ & $\mathrm{X}$ & $\begin{array}{l}\text { 45,X[70\%]/ } \\
46, \mathrm{X}, \mathrm{r}(\mathrm{X})(\mathrm{p} 22.1 \sim 22.2->\mathrm{q} 21.1)[27 \%] / \\
46, \mathrm{X}, \mathrm{r}(\mathrm{X})(:: \mathrm{p} 22.1 \sim 22.2->\mathrm{q} 21.1:: \mathrm{q} 21.1->\mathrm{p} 22.1 \sim 22.2::)[2] / \\
47, \mathrm{X},-\mathrm{X},+\mathrm{r}(\mathrm{X})(:: \mathrm{p} 22.1 \sim 22.2->\mathrm{q} 21.1:: \mathrm{q} 21.1->\mathrm{p} 22.1 \sim 22.2::) \times 2[1]\end{array}$ & $26 \mathrm{y}$ & infertility \\
\hline R-29 & $\mathrm{Y}$ & $45, \mathrm{X}[? \%] / 46, \mathrm{X}, \mathrm{r}(\mathrm{Y})(:: \mathrm{p} 11.3->\mathrm{q} 11.2 ? 3:: \mathrm{q} 11.2 ? 3->\mathrm{p} 11.3::)[? \%]$ & adult & infertility \\
\hline
\end{tabular}


(BAC) probes, were applied. Labeling and application of the probes was done according to the manufacturer's instructions or as reported [11].

\section{RESULTS AND DISCUSSION}

In 29 cases with ring chromosomes, the chromosomal origin and content could be determined using molecular cytogenetics. The rings were derived from chromosome 4 (one case), 10 (one case), 13 (five cases), 14, (three cases), 18 (two cases), 21 (eight cases), 22 (three cases), X (five cases) and Y (one case). The exact breakpoints and mosaic states are summarized in Table 1 and examples of the FISH results are shown in Figure 1. In the following data, the obtained results were compared with the literature by chromosomal origin; afterwards, the chromosomal imbalances were analyzed, and finally, a conclusion was drawn.

Analyzed Rings by Chromosomal Origin. Numerous cases for ring chromosomes 4 have been reported previously [12-14]. Interestingly, those cases fall into two cytogenetic groups: one group where the ring is stable and the other group where it is unstable within the studied cells, as in case R-1. Further studies are necessary to rule out where this instability comes from, and what the clinical impact is. To the best of our knowledge, no clinically normal ring chromosome 4 case has yet been reported.

In case R-2, the first ever seen balanced ring formation involving chromosome 10 formed by the McClintock mechanism [2] is reported. The rearrangement was connected with clinical problems, as the ring was lost in $\sim 20.0 \%$ of the cells. Ring chromo-

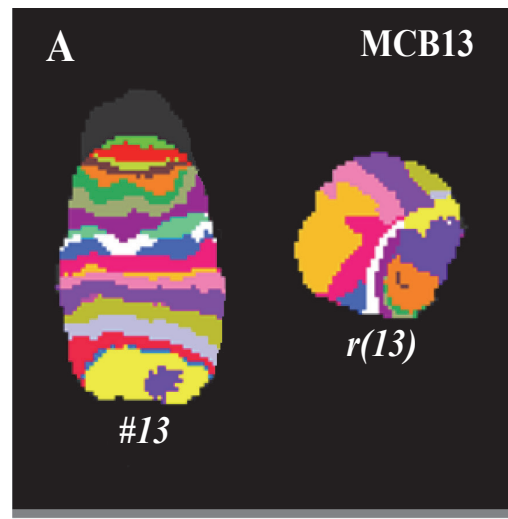

B

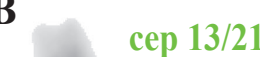

subtel 13qter

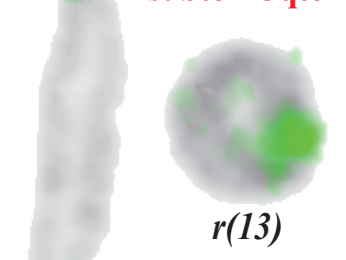

\#13 R-7

C

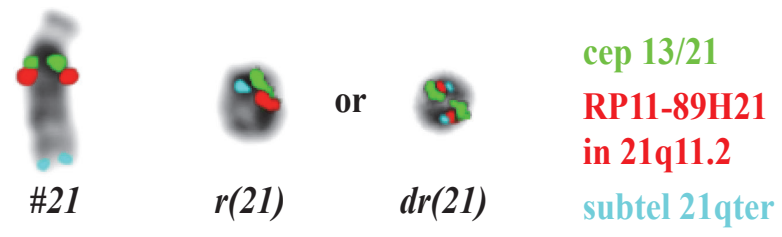

or plus

$\operatorname{der}(21)$

Figure 1. Representative results for the molecular cytogenetic characterization of the studied ring chromosomes. A) In case R-7, a ring chromosome derived from chromosome 13 [r(13)] was present as well as a normal chromosome 13 (\#13); breakpoints were characterized by $\mathrm{MCB}$ as $13 \mathrm{p} 1 ? 2$ and 13q34. B) Application of a subtelomeric probe for chromosome 13qter (subtel 13qter) together with a centromeric probe for chromosomes 13 and 21 (cep 13/21) confirmed a partial deletion in 13qter. C) Application of a centromeric probe for chromosomes 13 and 21 (cep13/21) with a subtelomeric probe for chromosome 21qter (subtel 21qter) in combination with a subcentromeric probe in 21q11.2 revealed the presence of three derivatives of a chromosome 21 in case R-23; a ring [r(21)], a double ring [ $\mathrm{dr}(21)]$ and a shortened derivative of chromosome 21 [der(21)] were observed. For final karyotype results, see Table 1. 
somes derived from chromosome 10 are rare (only about 10 cases) and were recently reviewed [15].

Martin et al. [16] suggested the existence of a ring chromosome 13 syndrome and gave an incidence of $1 / 58,000$ in live births. Here, five cases with ring chromosomes 13 were studied (R-3 to R7), all of them were clinically abnormal.

Similarly to chromosome 13 derived rings, chromosome $\mathbf{1 4}$ is also suggested as a specific syndrome [17]. In concordance with the literature, all three ring chromosome 14 cases studied here (R-8 to R10) had an abnormal pheno-type.

Ring chromosomes 18 were present in the prenatally studied cases R-11 and R-12. Here too, a recognizable syndrome was suggested [18]. Similar to chromosome 4 , for rings derived from chromosome 18 , cytogenetically stable (e.g., present two cases) and unstable rings [19] are reported.

Eight cases with ring chromosomes 21 were char-acterized in the present study (cases R-13 to $\mathrm{R}-20$ ). While cases R-13 to R-15 were unbalanced and led to clinical signs, two of the cases just detected were due to infertility (R-17 and R-20). As reported in [20], most, if not all ring chromosome 21 cases are mosaic, as the ones here described. A ring chromosome 21 syndrome was also postulated [21].

The three ring chromosome 22 cases were either cyto-genetically stable (R-21 and R-22) or unstable (R-23). The reason for the cytogenetic study was available only for case R-21; it was infertility, and in the literature there are several similar cases reported [22].

Turner syndrome is cytogenetically characterized by karyotype $45, \mathrm{X}$; in $\sim 5.0 \%$ of the cases, this main cell line is accompanied by a second one having 46 chromosomes due to an additional derivative $\mathrm{X}$ - or Y-chromosome [23]. Here, six such cases were characterized in more detail, as they had a ring derived from the $\boldsymbol{X}$-chromosome (cases R-24 to R-28) or the Y-chromosome (R-29). Interestingly, all cases were detected during adulthood and only two of them due to a suspicion of Turner syndrome (R-24 and R-26). The majority of the cases were referred due to infertility.

Ring Chromosome-Induced Imbalances. In all 29 studied ring chromosome cases (Table 1), euchromatic imbalances were present except for cases R-7, R-21 and R-22. In the latter, clinical data was available only for case R-21, and infertility was the only clinical problem observed there. Primarily, case R-2 did not have any imbalance due to a ring chromosome, but double ring formation and loss of the ring chromosome led to a partial tri - or monosomy in $23.0 \%$ of the patient's cells overall.

Imbalances were exclusively induced by the ring chromosome formation in case R-10. Moreover, in all the remaining 24 cases, imbalances were also caused by sec-ondary effects of the ring chromosome formation: $i)$ double ring formation: R-1, R-3 to R-5, R-8, R-15, R-16, R-18 to R-20, R-23, R-28 and $\mathrm{R}-29$; ii) ring doubling: R-1, R-15, R-26 and R-28; iii) complex changes of the ring itself: R-1, R-15 to $\mathrm{R}-17$ and $\mathrm{R}-23$; $\boldsymbol{i v}$ ) ring opening (including further rearrangements): R-1, R-8, R-11, R-13, R-15, R-17, $\mathrm{R}-19, \mathrm{R}-20$ and $\mathrm{R}-23$; $\boldsymbol{v}$ ) loss of the ring: R-1, R-4, R-6, R-8, R-9, R-12 to R-16, R-19 and R-24 to R-29.

Similar observations were also made for other ring chromosomes 22 . The idea that there might even be a "ring syndrome" irrespective of the chromosomal origin of the ring [24] might be due to the gross imbalances induced by these secondary changes [25].

\section{CONCLUSIONS}

In general, this report supports the idea that ring chro-mosome patients fall into two groups: a larger one with (severe) clinical signs and symptoms due to the ring chromosome and a smaller one with no obvious clinical problems apart from infertility. The latter can be due to gamete instability at meiosis due to the ring chromosome which leads to an increased breakdown [22]. This cytogenetic study of 29 rings also shows that chromosomal imbalances are secondary inducings in $\sim 85.0 \%$ of the cases by loss of the ring $(68.0 \%)$, double ring formation $(52.0 \%)$, ring opening $(36.0 \%)$, ring doubling $(16.0 \%)$ and complex changes of the ring itself $(16.0 \%)$.

\section{ACKNOWLEDGMENTS}

This study was supported in part by the DAAD (D07/ 00070 and Ph.D. fellowship to ABH), BMBF/ DLR (BLR 10/006), Else Kröner-Fresenius-Stiftung (2011_A42) and CAPES (Grant to RSG \#2333-112). Single cases were provided from Germany by Dr. Höls-Herpertz, Medizinische Genetik, Bensberg; Dr. Kunz, Humangenetische Apparategemeinschaft, Berlin; Dr. Belitz, Pränatale Diagnostic und 
Medizinische Genetic, Berlin; Dr. Tönnies, Charité, Berlin; Dr. Süss, Humangenetik, Cottbus; Dr. Junge, Genetic, Dresden; Dr. Bartz, Genetic, Düsseldorf; Dr. Zoll and Dr. Bartels, Institute für Humangenetik, Göttingen; Dr. Kroisel, Institute für Humangenetik, Greifs-wald; Dr. Schulze, Humangenetik, Hannover; Dr. Ovens-Räder, Humangenetik, München; Armenia: Dr. Mkrtchyan and Dr. Manveylan, Department of Genetics, Yerevan; Turkey: Dr. Ergun, Department of Medical Genetics, Ankara.

\section{REFERENCES}

1. Guilherme RS, Meloni VF, Kim CA, Pellegrino $\mathrm{R}$, Takeno SS, Spinner NB, et al. Mechanisms of ring chromosome formation; ring instability and clinical consequences. BMC Med Genet. 2011; 12(1): 171.

2. Baldwin EL, May LF, Justice AN, Martin CL, Led-better DH. Mechanisms and consequences of small supernumerary marker chromosomes: from Barbara McClintock to modern geneticcounseling issues. Am J Hum Genet. 2008; 82(2): 398-410.

3. Stankiewicz P, Brozek I, Helias-Rodzewicz Z, Wierzba J, Pilch J, Bocian E, et al. Clinical and molecular-cytogenetic studies in seven patients with ring chromosome 18. Am J Med Genet. 2001; 101(3): 226-239.

4. Stavropoulou C, Mignon C, Delobel B, Moncla A, Depetris D, Croquette MF, et al. Severe phenotype resulting from an active ring $\mathrm{X}$ chromosome in a female with a complex karyotype: characterisation and replication study. J Med Genet. 1998; 35(11): 932-938.

5. Liehr T. Small supernumerary marker chromosomes (http://www.fish.uniklinikum-jena.de/ sSMC.html [accessed 28/06/2012]).

6. Liehr T, Mrasek K, Weise A, Dufke A, Rodríguez L, Martínez Guardia N, et al. Small supernumerary marker chromosomes-progress towards a genotype-phenotype correlation. Cytogenet Genome Res. 2006; 112(1-2): 23-34.

7. Tönnies H, Hennies HC, Spohr HL, Neitzel $H$. Characterization of the first supernumerary tricentric ring chromosome 1 mosaicism by conventional and molecular cytogenetic techniques. Cytogenet Genome Res. 2003; 103 (12): 28-33.
8. Liehr T, Claussen U, Starke H. Small supernumerary marker chromosomes (sSMC) in humans. Cytogenet Genome Res. 2004; 107(1-2): 55-67.

9. Liehr T, Heller A, Starke H, Rubtsov N, Trifonov $\mathrm{V}$, Mrasek $\mathrm{K}$, et al. Microdissection based high resolution multicolor banding for all 24 human chromosomes. Int J Mol Med. 2002; 9(4): 335-339.

10. Weise A, Mrasek K, Fickelscher I, Claussen U, Cheung SW, Cai WW, et al. Molecular definition of high-resolution multicolor banding probes: first within the human DNA sequence anchored FISH banding probe set. J Histochem Cytochem. 2008; 56(5): 487-493.

11. Liehr T, Weise A, Heller A, Starke H, Mrasek $\mathrm{K}$, Kuechler A, et al. Multicolor chromosome banding (MCB) with YAC/BAC-based probes and region-specific micro dissection DNA libraries. Cytogenet Genome Res. 2002; 97(1-2): 43-50.

12. Lurie IW. Further study of genetic interactions: loss of short arm material in patients with ring chromosome 4 changes developmental pattern of del(4)(q33). Am J Med Genet. 1995; 56(3): 308-311.

13. Soysal Y, Balci S, Hekimler K, Liehr T, Ewers $\mathrm{E}$, Schoumans J, et al. Characterization of double ring chromosome 4 mosaicism associated with bilateral hip dislocation; cortical dysgenesis; and epilepsy. Am J Med Genet A. 2009; 149A(12): 2782-2787.

14. Chen CP, Lin SP, Su YN, Chern SR, Tsai EJ, $\mathrm{Wu} \mathrm{PC}$, et al. Mosaic ring chromosome 4 in a child with mild dysmorphisms; congenital heart defects and developmental delay. Genet Couns. 2011; 22(3): 321-326.

15. Gunnarsson C, Graffmann B, Jonasson J. Chromosome $\mathrm{r}(10)(\mathrm{p} 15.3 \mathrm{q} 26.12)$ in a newborn child: case report. Mol Cytogenet. 2009; 2(1): 25.

16. Martin NJ, Harvey PJ, Pearn JH. The ring chromosome 13 syndrome. Hum Genet. 1982; 61(1): 18-23.

17. Giovannini S, Frattini D, Scarano A, Fusco C, Bertani G, Della Giustina E, et al. Partial epilepsy complicated by convulsive and nonconvulsive episodes of status epilepticus in a 
patient with ring chromosome 14 syn-drome. Epileptic Disord. 2010; 12(3): 222-227.

18. Ono T, Okuma M, Hamada T, Motohashi N, Moriyama K. A case of ring chromosome 18 syndrome treated with a combinedorthodonticprosthodontic approach. Cleft Palate Craniofac J. 2010; 47(2): 201-210.

19. Carreira IM, Mascarenhas A, Matoso E, Couceiro AB, Ramos L, Dufke A, et al. Three unusual but cytogenetically similar cases with up to five different cell lines involving structural and numerical abnormalities of chromosome 18. J Histochem Cytochem. 2007; 55(11): 1123 1128.

20. Chen CP, Lin YH, Chou SY, Su YN, Chern SR, Chen YT, et al. Mosaic ring chromosome 21; monosomy 21; and isodicentric ring chromosome 21: prenatal diagnosis; molecular cytogenetic characterization; and association with 2-Mb deletion of 21q21.1-q21.2 and 5-Mb deletion of 21q22.3. Taiwan J Obstet Gynecol. 2012; 51(1): 71-76.
21. Capaccio P, Clemente IA, Marchisio P, Selicorni A, Esposito S, Pignataro L. Videoendoscopic rehabilitation of iatrogenous Stensen-ductacquired atresia in a patient with ring chromosome 21 syndrome and drooling. J Pediatr Surg. 2008; 43(11): e17-e20.

22. Rajesh H, Freckmann ML, Chapman M. Azoospermia and paternal autosomal ring chromosomes: case report and literature review. Reprod Biomed. Online 2011; 23: 466-470.

23. Liehr T, Mrasek K, Hinreiner S, Reich D, Ewers E, Bartels I, et al. Small supernumerary marker chromosomes (sSMC) in patients with a $45 ; \mathrm{X} / 46 ; \mathrm{X} ;+$ mar karyotype -17 new cases and a review of the literature. Sex Dev. 2007; 1(6): 353-362.

24. Kosztolányi G. Does "ring syndrome" exist? An analysis of 207 case reports on patients with a ring auto-some. Hum Genet. 1987; 75(2): 174-179.

25. Cote GB, Katsantoni A, Deligeorgis D. The cytogenetic and clinical implications of a ring chromosome 2. Ann Genet. 1981; 24(4): 231-235. 